Електронне наукове фахове видання "Ефективна економіка" включено до переліку

наукових фахових видань України з питань економіки

(Наказ Міністерства освіти і науки України від 11.07.2019 № 975)

www. economy.nayka.com. ua | № 10, 2019 | 31.10.2019 p.

DOI: $10.32702 / 2307-2105-2019.10 .6$

UDC 330.46:351.82: 338.14

O.V. Kuzmenko

Doctor of Economics, Associate Professor,

Head of the Department of Economic Cybernetics, Sumy State University

ORCID: 0000-0001-8575-5725

A.O. Boiko

PhD, Associate Professor,

Associate Professor of the Department of Economic Cybernetics, Sumy State University

ORCID: 0000-0002-1784-9364

H.M. Yarovenko

PhD, Associate Professor, Associate Professor of the Department of Economic Cybernetics,

Sumy State University

ORCID: 0000-0002-8760-6835

T. V. Dotsenko

PhD Student of the Department of Economic Cybernetics, Sumy State University

ORCID: 0000-0001-5713-2205

\title{
DATA MINING-BASED ASSESSEMENT OF THE RISK OF USING FINANCIAL INTERMEDIARIES FOR MONEY LAUNDERING
}

\author{
О. В. Кузьменко, \\ д. е. н., дочент, завідувач кафедри економічної кібернетики, \\ Сумський державний університет \\ А. О. Бойко, \\ к. е. н., дочент, дочент кафедри економічної кібернетики, \\ Сумський державний університет \\ Г. М. Яровенко, \\ к. е. н., доиент, дочент кафедри економічної кібернетики, \\ Сумський державний університет \\ Т. В. Доценко,
}

аспірант кафедри економічної кібернетики, Сумський держсавний університет

\section{ОЦІНЮВАННЯ РИЗИКУ ВИКОРИСТАННЯ ФІНАНСОВИХ ПОСЕРЕДНИКІВ 3 МЕТОЮ ЛЕГАЛІЗАЦІЇ КРИМІНАЛЬНИХ ДОХОДІВ НА ОСНОВІ ІНТЕЛЕКТУАЛЬНОГО АНАЛІЗУ ДАНИХ}

The paper deals with the mathematical economic modeling of the neural network describing the dependence of the risk of using financial intermediaries for money laundering on factors. Implementation of the proposed approach involved a multilayer perceptron (MLP) and a network based on radial basis functions (RBF). The BFGS algorithm was used to build a neural network based on the multilayer perceptron (MLP). The RBFT algorithm was used to construct a neural network based on radial basis functions (RBF). Data mining in the context of identifying key factors of the investigated risk was based on the collinearity study by applying sigma-limited parameterization and correlation analysis of the dependence of both the regressand on each of the regressors, as well as the factors among themselves. It is proposed to use the Statistica software, 
the Analysis package, the Advanced Methods tab, the GLM General Linear Models tab for data mining. A data set was generated for 215 countries of the world for 2017 to conduct the study. It was implemented the ranking of the predictors by the degree of their influence on the response: 1) Corruption Perceptions Index; 2) internally displaced persons, new displacement associated with conflict and violence (number of cases) 3) Happy Planet Index; 4) claims on the central government; 5) bank secrecy; 6) Global Terrorism Index; 7) gross domestic product per capita. The constructed models of neural networks are represented by architecture (the number of layers and hidden neurons), performance and error (training, control, test), learning algorithm, as well as error functions, active hidden and active output neurons. The reliability of the presented models is based on the following criteria: the criteria given in the columns "Training Performance", "Control Performance", "Test Performance". The risk of using financial intermediaries for money laundering for the period 2019 - 2023 has been predicted, showing its gradual growth since 2020. It is proved that the predicted risk values of using financial intermediaries for money laundering, regardless of the rather low predicted level for 2019, tend to increase rapidly in the near term.

В статті побудовано економіко-математичні моделі нейронної мережі залежності ризику використання фінансових посередників з метою легалізації коштів, отриманих незаконним иляхом, від факторних ознак. Реалізація запропонованої методики відбувалась у вигляді багатошарового персептрону MLP та мережі на основі радіальних базисних функцій.

Для побудови нейронної мережі типу багатошарового персептрону MLP використано алгоритм BFGS. Для побудови нейронної мережі на основі радіальних базисних функиій RBF використано алгоритм RBFT. Інтелектуальний аналіз даних в розрізі виявлення ключових факторів досліджуваного ризику проведений на основі дослідження колінеарності шляхом застосування сигма-обмеженої параметризачії та кореляційного аналізу залежності як регресанда від кожного із індикаторів регресорів, так і факторів між собою. Проведене ранжування факторів за ступенем їх впливу на відгук: 1) індекс сприйняття корупиії; 2) внутрішньо переміщені особи, нові переміщення, пов'язані з конфліктом та насильством (кількість випадків); 3) світовий індекс щүастя; 4) позови до центрального уряду; 5) банківська таємниия; 6) глобальний індекс тероризму; 7) валовий внутрішній продукт на душу населення.

Побудовані моделі нейронних мереж представлені архітектурою (кількістю шарів та прихованих нейронів), продуктивністю та помилкою (навчальною, контрольною, тестовою), алгоритмом навчання, а також функиіями помилки, активних прихованих та активних вихідних нейронів. Достовірність представлених моделей доведена на основі критерії: «Продуктивність навчання», «Контрольна продуктивність», «Тестова продуктивність». Проведено прогнозування ризику використання фінансових посередників з метою легалізації кримінальних доходів на період 2019 - 2023 рр., яка засвідчило його поступове зростання починаючи з 2020 р. Доведено, щчо прогнозні значення ризику використання фінансових посередників з метою легалізації кримінальних доходів, незалежно від досить низького прогнозного рівня 2019 року, мають тенденщію до стрімкого зростання в найближчій перспективі.

Keywords: money laundering risk; neural network; multilayer perceptron; network based on radial basis functions; prediction.

Ключові слова: ризик легалізації кримінальних доходів; нейронна мережа; багатошаровий персептрон; мережа на основі радіальних базисних функиій; прогнозування.

Statement of the problem in general terms and its relationship with important scientific and practical tasks. In the modern economic world, which is characterized by the rapid development of the global financial system and the rapid growth of information technologies for the implementation of financial transactions, the problems of global shadowing of economic processes, as well as money laundering, are becoming more acute. The solution to this problem requires the introduction of an effective system for assessing the risk of using financial intermediaries for money laundering. Data mining is of particular importance among modern developments against money laundering. 
Such innovations include neural networks that are adapted to the study of the complex dependencies inherent in modern financial transactions in the context of information constraints. Consequently, the solution to the problem of assessing the risk of using financial intermediaries for money laundering with new, non-standard methods of analysis and modeling of economic processes is becoming more relevant.

Analysis of recent studies and publications, which initiated the search for the solution to this problem and on which the author relies, highlighting previously unresolved parts of the general problem, which are discussed in this paper. Scientists V. Bilous [17], S. Hurzhii, A. Kopylenko, Ya. Yanushevych [18], R. Marchuk, A. Popov, V. Onisiev [19], V. Zakharov [22] and other scientists study the general theoretical, organizational and legal issues of combating money laundering and terrorist financing. Some aspects of the assessment and management of the risk of money laundering and terrorist financing are highlighted in the works of the following scientists: V. Kadnichanska, T. Romas [24], N. Moskalenko, N. Klimchuk [27] and other. Global issues of the analysis of international experience in using a risk-based approach against money laundering in the foreign economic activity are revealed in their studies by N. Vnukova, A. Kolodiziev, I. Chmutova [20], O. Smahlo [30]. The solution to more specialized problems of assessing and managing risks of money laundering with the help of banks is described by A. Berezhnyi [16] S. Dmytrov, A. Merenkova, T. Medvid, O. Vashchenko [21], V. Rysin [28], M. Khudokormova [31], I. Chmutova [32].

Such scientists as H. Setlak [29], M. Mozolevska, A. Stavytskyi [26], D. Ivanov [23], A. Matviichuk [25] work in the area of specific issues on the use of neural networks as a method of prediction in the financial sphere.

Research objective. The purpose of the paper is the mathematical economic modeling of the neural network describing the dependence of the risk of the use of financial intermediaries for money laundering and predicting the possible values of this risk in the short term. Achievement of this goal requires solving a number of tasks: identification of key risk factors; description of architecture, performance, error (training, control, test), learning algorithm, error functions, active hidden and active output neurons of a multilayer perceptron and a network based on radial basis functions; risk prediction; estimation of statistics of predicted values and sensitivity analysis of neural network models.

Statement of basic research materials with full justification for the scientific results. The study of the risk of using financial intermediaries for money laundering involved the selection of the most relevant indicators and formation of a certain sequence of its calculation. Thus, we will consider the steps of the proposed scientific and methodological approach in more detail.

Step 1. Formation of the statistical base of the study. A data set was generated for 215 countries of the world for 2017 to conduct the study. These figures represent statistical information that has been obtained from official websites of the world organizations. Thus, the authors selected 1 regressand - the level of risk of using financial intermediaries for money laundering from the results of previous studies [33] and 7 regressors: from the official website of the World Bank - gross domestic product per capita (GDP); claims on the central government; internally displaced persons, new displacement associated with conflict and violence (number of cases) [3]; based on the data from the Organization for Economic Cooperation and Development - banking secrecy [4]; from the website of Transparency International - Corruption Perceptions Index [5]; from research materials of the Institute of Economics and Peace Global Terrorism Index [6]; according to Happy Planet Index [7].

The rationale for the inclusion of the specified set of indicators is the results of collinearity studies by applying sigma-limited parameterization (Figure 1) and correlation analysis of the dependence of both the regressand on each of the regressors, as well as the factors among themselves (Figure 2). It is proposed to use the Statistica software, the Analysis package, the Advanced Methods tab, the GLM General Linear Models tab for such data mining as identifying key factors.

\begin{tabular}{|c|c|c|c|c|c|c|c|c|}
\hline \multirow[b]{2}{*}{ Effect } & \multicolumn{8}{|c|}{$\begin{array}{l}\text { Collinearity statistics for members in the equation } \\
\text { Sigma-limited parameterization }\end{array}$} \\
\hline & Toleran & $\begin{array}{r}\text { Dispersi } \\
\text { Infl fac }\end{array}$ & $\begin{array}{c}\mathrm{R} \\
\text { square }\end{array}$ & $\begin{array}{c}\text { Risk of mor } \\
\text { launderins } \\
\text { Beta }\end{array}$ & $\begin{array}{c}\text { Risk of mor } \\
\text { launderin } \\
\text { Private }\end{array}$ & $\begin{array}{r}\text { Risk of mon } \\
\text { laundering } \\
\text { Semi-priva }\end{array}$ & $\begin{array}{c}\text { Risk of mor } \\
\text { launderin } \\
t\end{array}$ & $\begin{array}{c}\text { Risk of mor } \\
\text { launderin } \\
p\end{array}$ \\
\hline GDP per capita (curren & 0,916 & 1,092 & 0,084 & $-0,033$ & $-0,044$ & $-0,032$ & $-0,432$ & 0,667 \\
\hline Bank Secrece & 0,500 & 2,000 & 0,500 & 0,099 & 0,098 & 0,070 & 0,962 & 0,338 \\
\hline Claims on central gover & 0,878 & 1,138 & 0,122 & $-0,151$ & $-0,195$ & $-0,142$ & $-1,944$ & 0,055 \\
\hline Internally displaced per & 0,719 & 1,390 & 0,281 & $-0,222$ & $-0,255$ & $-0,188$ & $-2,579$ & 0,011 \\
\hline Corruption Perceptions & 0,399 & 2,506 & 0,601 & $-0,588$ & $-0,461$ & $-0,371$ & $-5,092$ & 0,000 \\
\hline Global Terrorism Index & 0,722 & 1,385 & 0,278 & 0,087 & & 0,074 & 1,014 & 0,313 \\
\hline Happy Planet Index & 0,450 & 2,220 & 0,550 & $-0,186$ & $-0,172$ & $-0,125$ & $-1,713$ & 0,090 \\
\hline
\end{tabular}

Figure 1 - Statistics of collinearity of indicators of the statistical base

An analysis of Figure 1 (beta coefficients - the Risk of money laundering graph) indicates the feasibility of ranking the predictors by the degree of their influence on the response as follows: 1) Corruption Perceptions Index; 2) internally displaced persons, new displacement associated with conflict and violence (number of cases) 3) Happy Planet Index; 4) claims on the central government; 5) bank secrecy; 6) Global Terrorism Index; 7) gross domestic product per capita; but only the first two have a strong influence, while the others have a moderate one.

In addition, the partial correlation coefficients (Risk of money laundering graph in Figure 1) show the degree of influence of one predictor on the response, assuming that other predictors are fixed at a constant level. The calculated 
values of this indicator confirm the above conclusion that there is a significant influence of only the Corruption Perceptions Index and the indicator of internally displaced persons, new displacement associated with conflict and violence (number of cases) on the risk of using financial intermediaries for money laundering, as well as moderate influence of other indicators.

In terms of the analysis of the determination coefficient (column $\mathrm{R}$ in Figure 1), i.e. the square of the coefficient of multiple correlations between this variable and others variables, we note the moderation of all indicators, but the relationship between the three predictors (bank secrecy, Corruption Perceptions Index, Happy Planet Index) and all others is much greater than for four unspecified predictors.

\begin{tabular}{|c|c|c|c|c|c|c|c|c|}
\hline \multirow[b]{2}{*}{ Effect } & \multicolumn{8}{|c|}{$\begin{array}{l}\text { Correlations of vectors in the plan matrix } \mathrm{X} \\
\text { Corelate. matrix for vectors in the plan } \mathrm{X}\end{array}$} \\
\hline & $\begin{array}{c}\text { GDP pe } \\
\text { capita } \\
\text { (curren } \\
\text { LCU) }\end{array}$ & $\begin{array}{c}\text { Bank } \\
\text { Secrec } \\
\end{array}$ & \begin{tabular}{|c|} 
Claims or \\
central \\
governme \\
etc. ( $\%$ \\
GDP) \\
\end{tabular} & \begin{tabular}{|}
$\begin{array}{c}\text { Internally displaced } \\
\text { persons, new } \\
\text { displacement associa } \\
\text { with conflict and viole } \\
\text { (number of cases) }\end{array}$ \\
\end{tabular} & \begin{tabular}{|c|} 
Corrup \\
on \\
Percep \\
ons \\
Index \\
\end{tabular} & $\begin{array}{c}\text { Global } \\
\text { Terrori: } \\
\text { m Inde } \\
\end{array}$ & $\begin{array}{l}\text { Happy } \\
\text { Planet } \\
\text { Index }\end{array}$ & $\begin{array}{c}\text { Risk ol } \\
\text { money } \\
\text { launde } \\
\text { ng }\end{array}$ \\
\hline GDP per capita (current LCU) & 1,000 & 0,110 & $-0,117$ & 0,032 & $-0,090$ & 0,086 & $-0,014$ & 0,052 \\
\hline Bank Secrece & 0,110 & 1,000 & 0,291 & $-0,255$ & 0,611 & $-0,100$ & 0,583 & $-0,368$ \\
\hline Claims on central government & $-0,117$ & 0,291 & 1,000 & $-0,113$ & 0,134 & $-0,008$ & 0,177 & $-0,206$ \\
\hline Internally displaced persons, $r$ & 0,032 & $-0,255$ & $-0,113$ & 1,000 & $-0,242$ & 0,484 & $-0,215$ & $\mid-0,006$ \\
\hline Corruption Perceptions Index & $-0,090$ & 0,611 & 0,134 & $-0,242$ & 2. 1,000 & $-0,259$ & 0,716 & $-0,646$ \\
\hline Global Terrorism Index & 0,086 & $-0,100$ & $-0,008$ & 0,484 & $-0,259$ & 1,000 & $-0,200$ & | 0,158 \\
\hline Happy Planet Index & $-0,014$ & 0,583 & 0,177 & $-0,215$ & 0,716 & $-0,200$ & 1,000 & $-0,545$ \\
\hline Risk of money laundering & 0,052 & $-0,368$ & $-0,206$ & $-0,006$ & $-0,646$ & 0,158 & $-0,545$ & 1,000 \\
\hline
\end{tabular}

Figure 2 - Correlation matrix of indicators of statistical base of the study

At the same time, studies of the correlation matrix (Figure 1) suggest that there is moderate reverse causality between the level of risk studied and the Corruption Perceptions Index and the Happy Planet Index, as evidenced by the corresponding correlation coefficients of -0.6466 and -0.5454 . In addition, there is a weak reverse causality between the effective attribute and factor attribute banking secrecy. In the context of other regressors, namely: gross domestic product per capita (GDP), claims on the central government, internally displaced persons, new displacement associated with conflict and violence (number of cases), Global Terrorism Index, Happy Planet Index, the relationship is not confirmed at $95 \%$ significance.

In terms of the analysis of the multicollinearity of regressors, we observe only one case of a high degree of dependence between the Corruption Perceptions Index and the Happy Planet Index since the corresponding correlation coefficient is 0.71 . Despite the need to remove one of these factors from the model to mitigate the collinearity problem of the corresponding vectors, we propose leaving both indicators, since, from an economic point of view, both indicators are of considerable interest in terms of the study of the risk of using financial intermediaries for money laundering.

Step 2. Formation of research methodology. Justification of the methods of mathematical formalization of the problem. Risk assessment of financial intermediaries for money laundering using the principles of data mining is proposed to be carried out by building a neural network. It is proposed to present mathematical economic models of the neural network describing the risk of using financial intermediaries for money laundering on factors in the form of a multilayer perceptron and a network based on radial basis functions.

Thus, the mathematical economic model of the neural network of the risk under study takes the following form [2]:
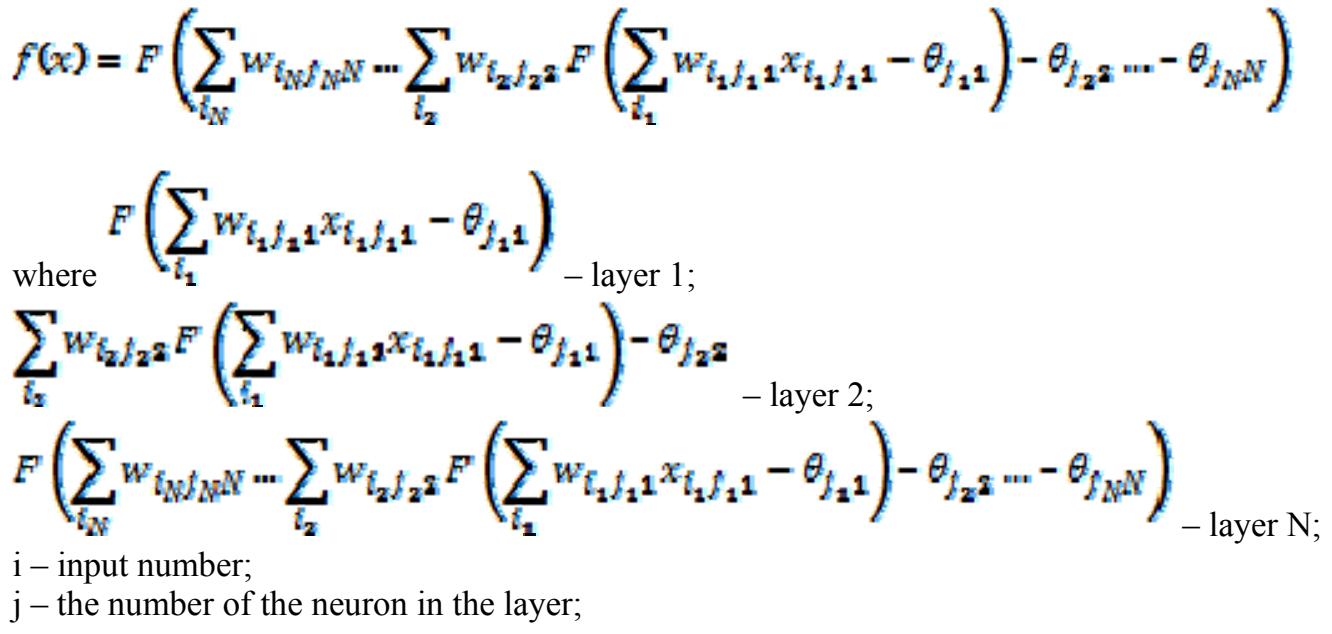
$x_{\delta_{2} \delta_{2} 2}$ - the $\mathrm{i}$-th input signal of the $\mathrm{j}$-th neuron in layer 1 ;

$w_{t_{N}} t_{N} N$ - the weighting factor of the i-th input signal of the $\mathrm{j}$-th neuron in layer $\mathrm{N}$;

$\theta_{f_{N}}{ }^{N}-$ threshold level of $\mathrm{j}$-th neuron in layer $\mathrm{N}$.

In turn, the mathematical economic model of the neural network of the risk of using financial intermediaries for money laundering in the form of a network based on radial basis functions takes the following form $[8,9]$ :

$$
f(x)=\sum_{i=1}^{N} w_{i} \varphi\left(\left\|x-x_{i}\right\|\right)
$$

where $-w^{v_{\mathrm{a}}}$ - the weighting coefficient of the i-th input signal;

$x_{i}$ - centers of radial basis functions.

The Broyden-Fletcher - Goldfarb-Shanno (BFGS) algorithm is used to build a neural network such as the MLP multilayer perceptron. It is one of the most comprehensive quasi-Newton methods that consists in implementing an iterative procedure of numerical optimization to search for a local extremum of a nonlinear function without restrictions. The BFGS algorithm involves the implementation of the following sequence of steps [15]:

1) determining the weighting coefficients by random small quantities and the initial approximation value of the inverse Hessian $\mathrm{V}-$ a matrix of size $\mathrm{nxn}$, where $\mathrm{n}$ is the length of the gradient vector $\mathrm{g}$.

2) calculation of the gradient $\mathrm{g}$.

3) calculating the correlation of weighting coefficients $\Delta W^{E}-g \cdot \tau, W_{k+1}-W_{k}-\Delta W^{2}$, where ${ }^{\tau}$ is the parameter of the learning rate.

4) defining a new gradient value $g-g(W)$ given the previous value $g p$, and calculating the gradient change $\Delta g=g-g_{p}$.

5) calculation of inverse hessian (r gradient change, $\mathrm{s}$ weight change):

$$
\begin{gathered}
V_{k+1}=V_{k}-\frac{V_{k} \cdot s \cdot s^{T} \cdot V_{k}}{s^{T} \cdot V_{k} \cdot z}+\frac{r \cdot r^{T}}{s^{T} \cdot s}, \\
r=\Delta g_{k}=g_{k}-g_{k-1} \\
s=\Delta W_{k}-W_{k}-W V_{k-1}
\end{gathered}
$$

6) calculation of change of weighting coefficients $\Delta W=W \cdot g$ and corresponding adjustment of parameters $W_{[\mathrm{I}}=W_{\mathrm{C}]}-\Delta \mathrm{WV}^{2}$.

7) determining the value of the error. If the error exceeds the value of the specified accuracy, it is necessary to repeat the algorithm, starting from step 4. Otherwise, the algorithm stops.

The RBFT algorithm is used to construct a neural network based on the radial basis functions (RBF).

It is suggested to use the Statistica software, Analysis package, Neural Network tab, Regression tab to implement this stage. It is feasible to determine weighting coefficients using the least-squares method.

Step 3. Practical testing of design calculations. We will carry out mathematical economic modeling of two

\begin{tabular}{|c|c|c|c|c|c|c|c|c|c|c|c|}
\hline \multicolumn{12}{|c|}{ Model results } \\
\hline $\mathrm{N}$ & Architecture & $\begin{array}{c}\text { Productivity, } \\
\text { training }\end{array}$ & $\begin{array}{c}\text { Productivity } \\
\text { control }\end{array}$ & $\begin{array}{c}\text { Test. } \\
\text { productivity }\end{array}$ & $\begin{array}{l}\text { Learning } \\
\text { error }\end{array}$ & $\begin{array}{c}\text { Control } \\
\text { error }\end{array}$ & $\begin{array}{l}\text { Test } \\
\text { error }\end{array}$ & $\begin{array}{l}\text { Learning } \\
\text { algorithm }\end{array}$ & Error function & $\begin{array}{c}\text { Function of } \\
\text { active hidden } \\
\text { neurons }\end{array}$ & $\begin{array}{c}\text { Function of } \\
\text { active outpu } \\
\text { neurons }\end{array}$ \\
\hline 1 & MLP 7-4-1 & 866524 & & $0,80988 \overline{1}$ & $0,00605 \mathrm{C}$ & & 011871 & BFGS 26 & & Hyperbolic & Hyperbolic \\
\hline 2 & MLP 7-7-1 & $0,78895 \varepsilon$ & 0,840554 & 0,819724 & 0,009235 & בים70078 & $01150 €$ & BFGS 13 & Sums. squares. & Logistic & \\
\hline 3 & MLP 7-6-1 & $0,86851 \varepsilon$ & 0,732577 & $0,84199 \varepsilon$ & 0,005977 & I,012816 & 010205 & BFGS 21 & Sums. squares. & Logistic & Hyperbolic \\
\hline 4 & MLP 7-6-1 & 0,808654 & $0,85048 \mathrm{C}$ & $0,83823 \epsilon$ & $0,00840 \subseteq$ & I,00723C & $01028 \approx$ & 513 & Sums. squares. & & \\
\hline 5 & MLP 7-4-1 & $0,84542 \varepsilon$ & $2861 \subseteq$ & $917 \mathrm{c}$ & 0,006942 & & $01143 C$ & 12 & Sums. s & & Exponentia \\
\hline 6 & MLP 7-10-1 & 0,795541 & 0,795391 & $0,81381 \approx$ & $0,00889 \mathrm{c}$ & $1,01009 \subseteq$ & $01142 C$ & BFGS 9 & Sum & nential & \\
\hline 7 & MLP 7-8-1 & 0,828275 & $0,82610 \varepsilon$ & $0,84880 \approx$ & 0,007645 & 10000 & 009922 & BFGS 19 & Sum & & oolic \\
\hline 8 & RBF 7-20-1 & 0,827427 & 0,691915 & $0,80893 \approx$ & 0,007637 & I,014047 & 012504 & RBFT & Sums. s & & Identical \\
\hline 9 & RBF 7-20-1 & 0,855934 & $0,71694 \varepsilon$ & 0,804731 & 0,006475 & I,01282C & $01242 C$ & RBFT & Sums. squares. & Gaussian & Identical \\
\hline 10 & MLP 7-9-1 & 0,790786 & $0,83773 \varepsilon$ & $0,84621 \approx$ & $0,00913 C$ & I,007997 & 00975 ₹ & BFGS 12 & Sums. squares. & Logistic & Identical \\
\hline
\end{tabular}
types of neural networks (MLP multilayer perceptron and networks based on radial basis functions (RBF)) describing the regression dependence of the risk of using financial intermediaries for money laundering on relevant regressors and will systematize the results in a tabular form (Figure 3).

Figure 3 - The results of the modeling of neural networks of regression dependence of the risk of using financial intermediaries for money laundering on regressors 
The analysis of Figure 3 shows a much larger spectrum of constructed neural networks in the form of MLP multilayer perceptron ( $80 \%$ of models) than networks based on radial basis functions RBF ( $20 \%$ of models). All presented models are characterized by a high level of adequacy as evidenced by the criteria given in the columns "Training Performance", "Control Performance", "Test Performance". At the same time, the performance of MLP models has a much larger range of variation of correlation coefficients - from 0.7890 to 0.8685 (training sample), from 0.7286 to 0.8505 (control sample), from 0.8099 to 0.8448 (test sample) than RBF models - respectively, from 0.8274 to 0.8559 (training sample), from 0.6919 to 0.7169 (control sample), from 0.8047 to 0.8089 (test sample). The reliability of 10 constructed models of neural networks is confirmed by the error indicator within the framework of the training, control and test samples, which takes values close to zero.

To further use the constructed models for predicting the level of risk of using financial intermediaries for money laundering, we will choose two MLP perceptron models and RBF-based networks with better adequacy characteristics, namely: the first model with MLP 7-4- architecture 1 (a total of 7 layers, a number of hidden layers -4), the third model with MLP 7-6-1 architecture (a total of 7 layers, a number of hidden layers - 6, Figure 4), the eighth model with RBF 7-20-1 architecture (a total of 7 layers, a number of hidden layers - 20), a ninth model RBF 7-20-1 architecture (a total of 7 layers, a the number of hidden layers - 20). The BFGS algorithm is used to build a neural network such as the multilayer perceptron MLP 7-4-1 and MLP 7-6-1, the RBFT algorithm is used, respectively, to build the neural network based on the radial basis functions RBF 7-20-1.

\begin{tabular}{|c|c|c|}
\hline \multirow[b]{2}{*}{ WeightID } & \multicolumn{2}{|l|}{ Ваги } \\
\hline & $\begin{array}{l}\text { Connection } \\
\text { 1.MLP 7-6-1 }\end{array}$ & $\begin{array}{c}\text { Weight } \\
\text { values } \\
\text { 1.MLP 7-6- }\end{array}$ \\
\hline 1 & GDP per capita (current LCU) --> hidden neuI & 0,2422 \\
\hline 2 & Bank Secrece --> hidden neuro & $-3,5638$ \\
\hline 3 & Claims on central government, etc. ( $\%$ GDP) --> hidden neı & $-0,3559$ \\
\hline 4 & $\begin{array}{r}\text { Internally displaced persons, new displacement associated with conflict and violence (number of c } \\
\text { hidden neuron }\end{array}$ & 0,7627 \\
\hline 5 & Corruption Perceptions Index --> hidden neuı & $-3,3600$ \\
\hline 6 & Global Terrorism Index --> hidden neur & 2,8583 \\
\hline 7 & Happy Planet Index --> hidden neurc & $-1,9071$ \\
\hline 8 & GDP per capita (current LCU) --> hidden neuI & 0,0960 \\
\hline 9 & Bank Secrece --> hidden neuro & $-1,7483$ \\
\hline 10 & Claims on central government, etc. (\% GDP) --> hidden neı & 0,0107 \\
\hline 11 & $\begin{array}{r}\text { Internally displaced persons, new displacement associated with conflict and violence (number of c } \\
\text { hidden neuron }\end{array}$ & $-0,2683$ \\
\hline 12 & Corruption Perceptions Index --> hidden neuI & $-3,0323$ \\
\hline 13 & Global Terrorism Index --> hidden neur & 0,8873 \\
\hline 14 & Happy Planet Index --> hidden neurc & $-2,6978$ \\
\hline 15 & GDP per capita (current LCU) -->hidden neuI & 0,1488 \\
\hline 16 & Bank Secrece --> hidden neuro & $-1,7353$ \\
\hline 17 & Claims on central government, etc. (\% GDP) --> hidden neı & $-0,1046$ \\
\hline 18 & $\begin{array}{r}\text { Internally displaced persons, new displacement associated with conflict and violence (number of c } \\
\text { hidden neuron }\end{array}$ & $-0,5836$ \\
\hline
\end{tabular}

Figure 4 - Fragment of a seven-layer perceptron neural network architecture with 6 hidden layers MLP 7-6-1

A scatter diagram of theoretical (obtained by using four selected constructed neural networks) and the actual value of the risk of using financial intermediaries for money laundering is shown in Figure 5. Based on the visual correlation of neural networks built to predict the risk under study, it is necessary to note the high reliability of the selected model, as evidenced by a dense arrangement of actual values compared to theoretical (predictive ones found using the models). 


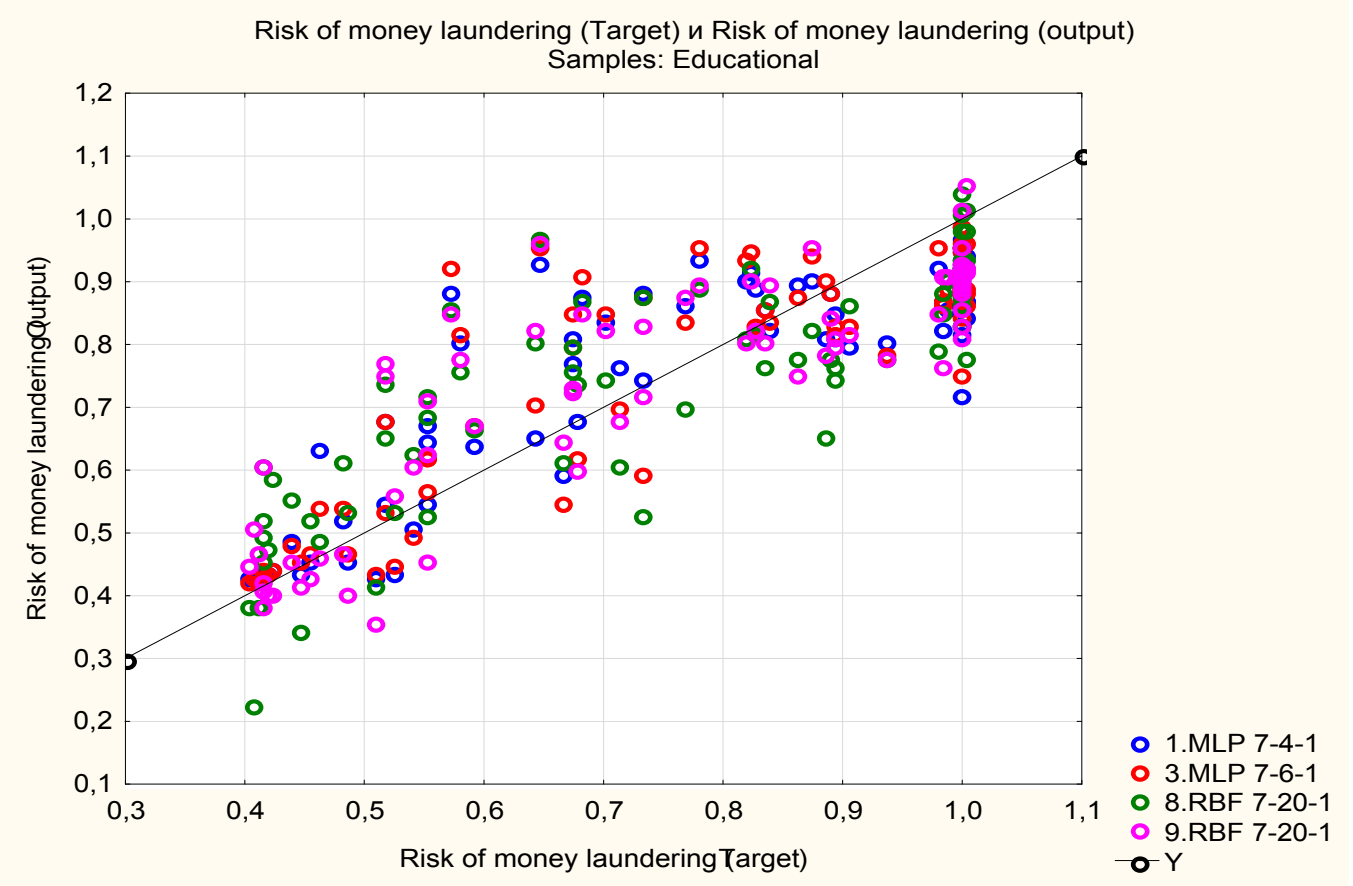

Figure 5 - Ratio of actual and projected levels of risk of using financial intermediaries for money laundering

A deep analysis of input predictors is important for the formalization of the risk of using financial intermediaries for money laundering using a neural network. Thus, we construct the corresponding scatterplots (Figure 6 - Figure 9).
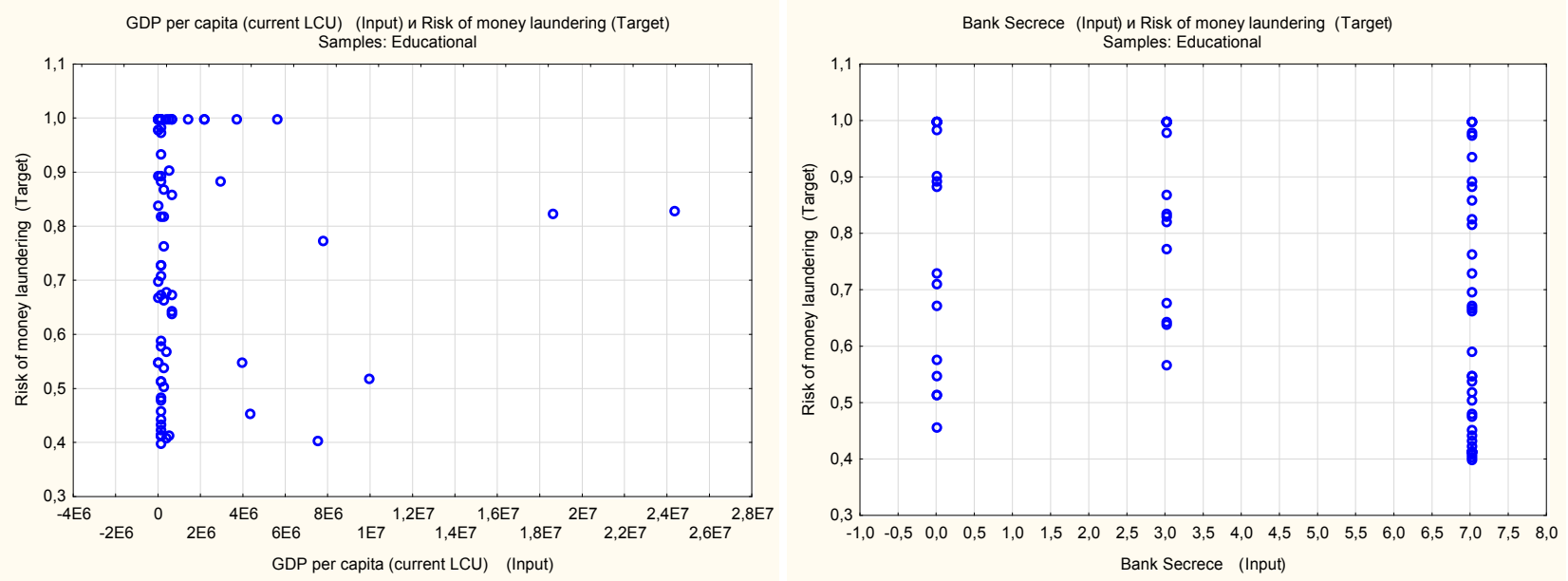

Figure 6 - Scatter diagrams of risk factors for the use of financial intermediaries for money laundering: gross domestic product per capita, bank secrecy

An analysis of the pairwise dependence of the effective attribute on gross domestic product per capita and bank secrecy indicates the following (Figure 6): the absence of a clear dependence of the risk of using financial intermediaries for money laundering on gross domestic product per capita, because despite the absence of a significant variation in the factor attribute, we observe a change in the effective one from 0.4 to 1.0; the value of the bank secrecy indicator is clearly grouped into 3 clusters, with the third cluster being the largest by volume, i.e. the increase of the value of this regressor will lead to the increase in the investigated level of risk. 

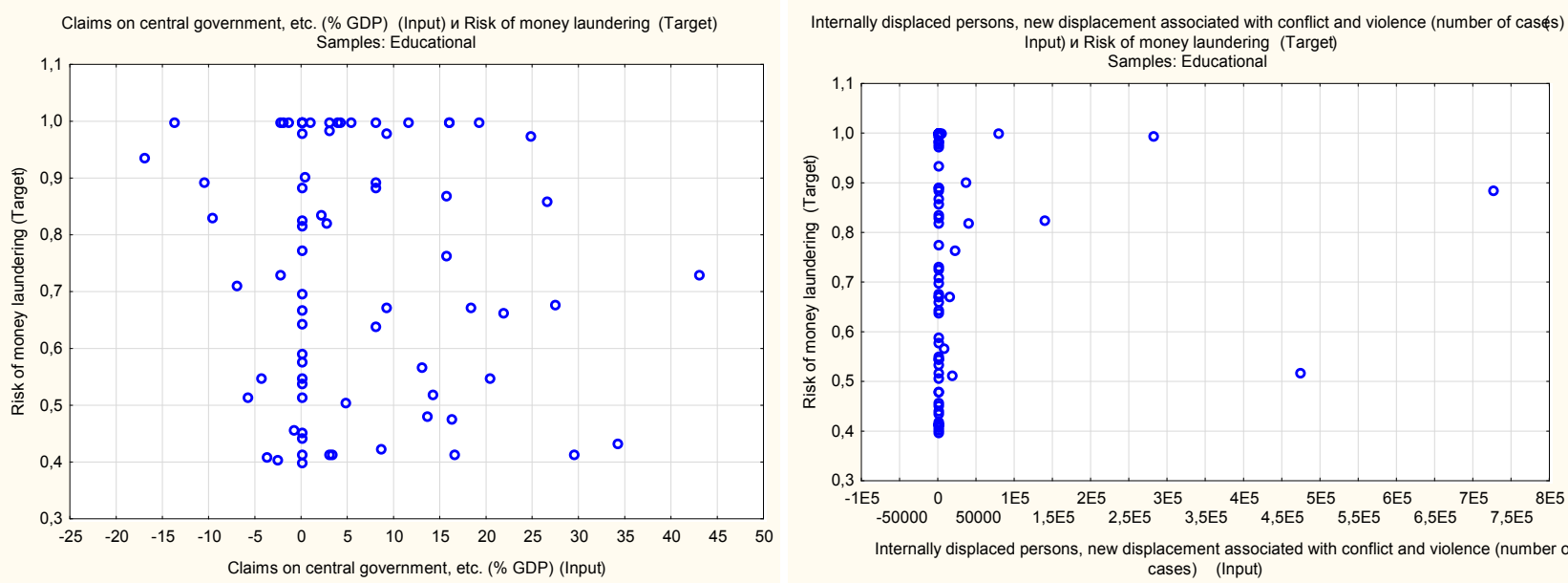

Figure 7 - Scatter diagrams of risk factors for the use of financial intermediaries for money laundering: claims to the central government, internally displaced persons, new displacement associated with conflicts and violence (number of cases)

In terms of the study of the dependence of the risk of using financial intermediaries for money laundering on claims on the central government (Figure 7), we observe a chaotic distribution, i.e. the absence of a clear relationship between the predictors under investigation. In terms of the indicator of internally displaced persons, new displacement associated with conflict and violence (the number of cases), similar to the case of GDP per capita, there is a lack of a clear dependence of the studied risk on this factor, because despite the absence of a significant variation in the factor characteristics, we observe change in the effective attribute from 0.4 to 1.0 .
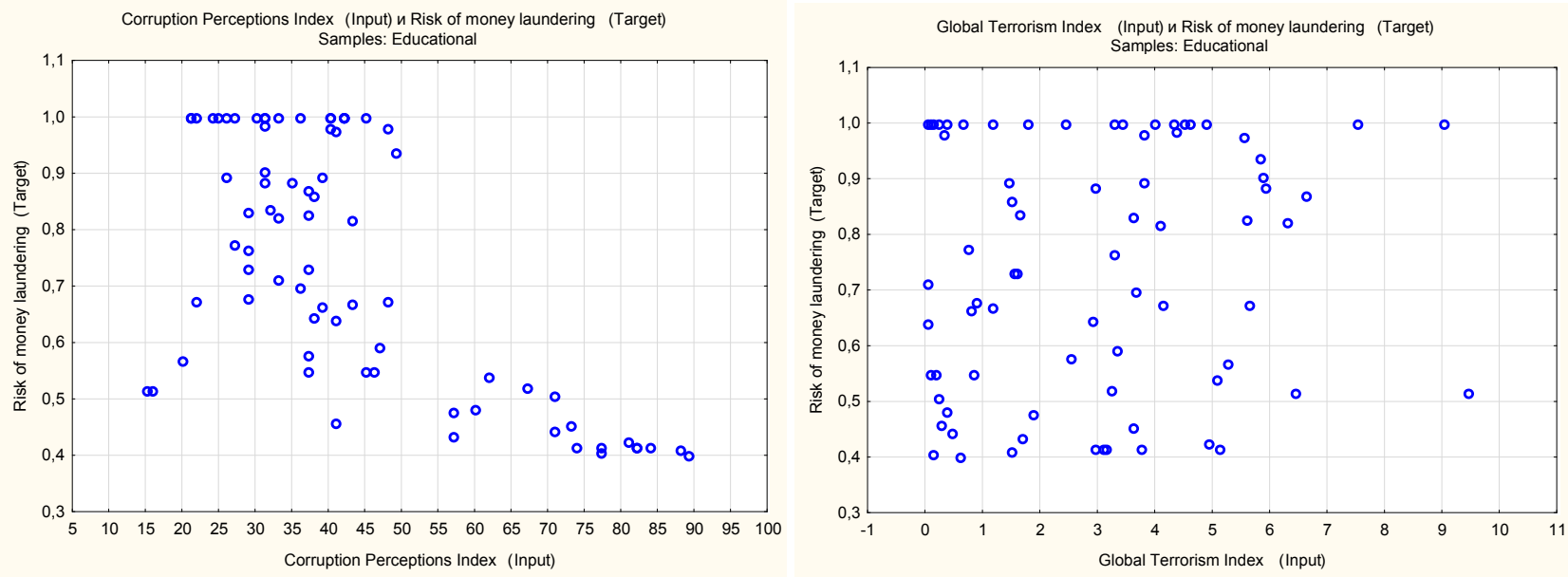

Figure 8 - Scatter diagrams of risk factors for the use of financial intermediaries for money laundering: Corruption Perceptions Index, Global Terrorism Index

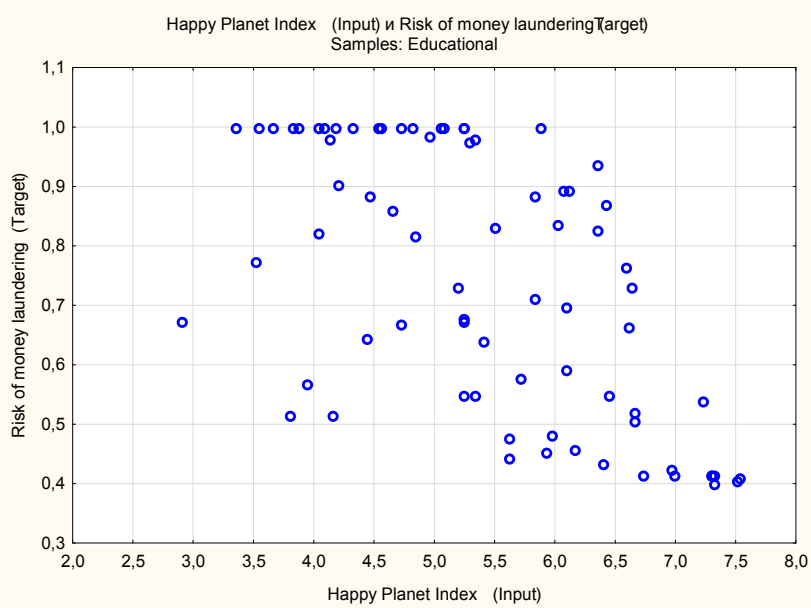

Figure 9 - Scatter diagrams of risk factors for the use of financial intermediaries for money laundering: Happy Planet Index 
In terms of the study of the influence of the Corruption Perceptions Index (Figure 8) and the Happy Planet Index (Figure 9) on the risk of using financial intermediaries for money laundering, we observe an average inversely proportional relationship, i.e. an increase in the factor attribute lowers the value of the effective one and vice versa. In the context of the study of the impact of the Global Terrorism Index, we observe a chaotic distribution.

In terms of the last but one of the most important stages of the presented methodology - predicting the level of the risk under study, there is a need for a preliminary detailed analysis of quality of the four neural networks constructed and described above: the multilayer perceptron MLP 7-4-1, MLP 7-6-1, the network based on radial basis functions RBF 7-20-1, RBF 7-20-1. For this purpose, we consider the statistics of the predicted values (Figure 10) and the sensitivity of the models of selected neural networks in terms of input predictors (Figure 11).

\begin{tabular}{|l|r|r|r|r|}
\hline \multirow{2}{*}{ Statistics } & \multicolumn{4}{l|}{$\begin{array}{l}\text { Statistics of predicted values } \\
\text { Target : Risk of money laundering }\end{array}$} \\
\cline { 2 - 5 } & 1. MLP 7-4-1 & 3. MLP 7-6-1 & \multicolumn{1}{l|}{8. RBF 7-20-1 } & 9. RBF 7-20-1 \\
\hline Minimum predicted values. (Educational) & 0,43035 & 0,42597 & 0,22755 & 0,36046 \\
\hline Maximum predicted values (Educational) & 0,97322 & 0,99047 & 1,04531 & 1,05707 \\
\hline Minimum predicted values. (Control) & 0,43214 & 0,42667 & 0,37610 & 0,45000 \\
\hline Maximum predicted values (Control) & 0,96293 & 0,99084 & 0,92952 & 0,90805 \\
\hline Minimum predicted values. (Test) & 0,42897 & 0,42666 & 0,42732 & 0,33787 \\
\hline Maximum prediction (Test) & 0,92754 & 0,96464 & 0,96360 & 0,94910 \\
\hline
\end{tabular}

Figure 10 - Statistics of the predicted values

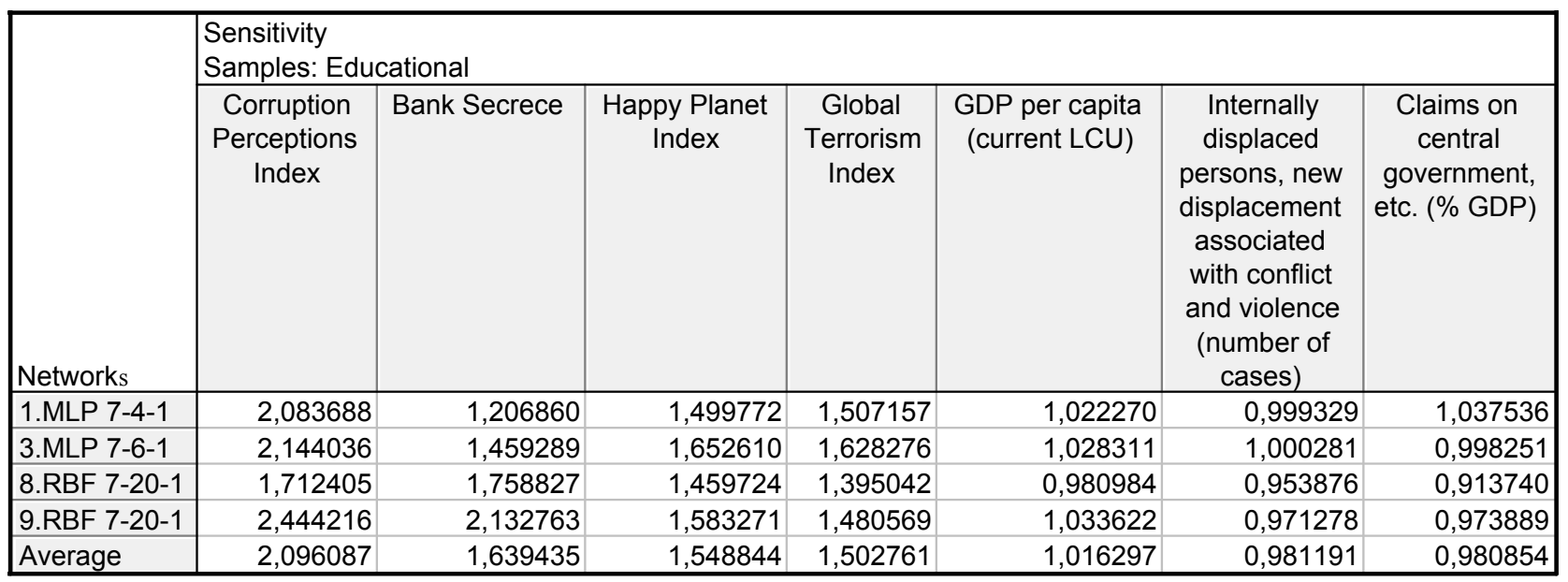

Figure 11 - Sensitivity of the models of selected neural networks in terms of input predictors

An analysis of the statistical characteristics of neural network models shown in Figures 10 and 11 indicates a high quality of the models (insignificant variation of the minimum and maximum levels both in the training, control and test samples) and an insignificant level of sensitivity of the models to the input data scale.

In terms of predicting the risk of using financial intermediaries for money laundering for the period 2019-2023, we will form (based on an expert approach) promising areas for the development of 7 regressors: gross domestic product per capita (GDP), claims on the central government, internally displaced persons, new displacement associated with conflict and violence (number of cases); bank secrecy; Corruption Perceptions Index; Global Terrorism Index; Happy Planet Index presented in Table 1.

Table 1 - Predicted values of the input statistical data of the risk assessment of the use of financial intermediaries for money laundering

\begin{tabular}{|c|c|c|c|c|c|c|c|}
\hline Series Name & 2017 & 2018 & 2019 & 2020 & 2021 & 2022 & 2023 \\
\hline \multirow[b]{2}{*}{ GDP per capita (current LCU) } & 70233.0 & 84190.3 & 105238 & 136809 & 177852 & 222315 & 277894 \\
\hline & $26 \%$ & $20 \%$ & $25 \%$ & $30 \%$ & $30 \%$ & $25 \%$ & $25 \%$ \\
\hline Bank Secrecy & 3 & 3.0 & 3 & 3 & 3.0 & 3 & 3 \\
\hline \multirow{2}{*}{$\begin{array}{l}\text { Claims on central government, } \\
\text { etc. ( } \% \text { GDP })\end{array}$} & 24.2 & 20.0 & 19 & 17 & 15 & 13 & 11 \\
\hline & $-12 \%$ & $-18 \%$ & $-5 \%$ & $-10 \%$ & $-10 \%$ & $-15 \%$ & $-15 \%$ \\
\hline \multirow{2}{*}{$\begin{array}{l}\text { Internally displaced persons, } \\
\text { new displacement associated } \\
\text { with conflict and violence } \\
\text { (number of cases) }\end{array}$} & 21000.0 & 12000.0 & 9600 & 8640 & 8208 & 7962 & 7882 \\
\hline & $-81 \%$ & $-43 \%$ & $-20 \%$ & $-10 \%$ & $-5 \%$ & $-3 \%$ & $-1 \%$ \\
\hline \multirow{3}{*}{$\begin{array}{l}\text { Corruption Perceptions Index } \\
\text { Global Terrorism Index }\end{array}$} & 30 & 32 & 28 & 22 & 17 & 13 & 10 \\
\hline & $3 \%$ & $7 \%$ & $-13 \%$ & $-21 \%$ & $-23 \%$ & $-24 \%$ & $-23 \%$ \\
\hline & 6.54 & 6.05 & 5.5 & 4.5 & 3.5 & 2.5 & 1.8 \\
\hline
\end{tabular}




\begin{tabular}{|l|r|r|r|r|r|r|r|}
\hline & $-8 \%$ & $-7 \%$ & $-9 \%$ & $-18 \%$ & $-22 \%$ & $-29 \%$ & $-28 \%$ \\
\hline Happy Planet Index & 4.25 & 4.41 & 4.65 & 4.71 & 5.95 & 5.11 & 5.25 \\
\hline
\end{tabular}

Analysis of the predicted values of the risk of using financial intermediaries for money laundering (Figure 12, columns $2-5$ ) for the period 2019 -2023 indicates fairly similar values (derived from the use of four neural networks): multilayer perceptron MLP 7- 4-1, MLP 7-6-1, radial basis function networks RBF 7-20-1, RBF 7-20-1. Therefore, it should be pointed out that the predicted risk values of using financial intermediaries for money laundering, regardless of the rather low predicted level for 2019 , tend to increase rapidly in the near term.

\begin{tabular}{|c|c|c|c|c|c|c|c|c|c|c|c|}
\hline & \multicolumn{11}{|c|}{ User Values Table } \\
\hline & \begin{tabular}{|c|} 
1.Risk of \\
money \\
laundering \\
(t)
\end{tabular} & $\begin{array}{c}\text { 3. Risk of } \\
\text { money } \\
\text { laundering } \\
\text { _(t) }\end{array}$ & $\begin{array}{c}\text { 8. Risk of } \\
\text { money } \\
\text { laundering } \\
\text { (t) }\end{array}$ & \begin{tabular}{|c|}
$\begin{array}{c}9 . \text { Risk } \\
\text { of } \\
\text { money } \\
\text { launder } \\
\text { ing_(t) }\end{array}$ \\
\end{tabular} & $\begin{array}{c}\text { GDP per } \\
\text { capita } \\
\text { (current } \\
\text { LCU) }\end{array}$ & $\begin{array}{c}\text { Bank } \\
\text { Secrece }\end{array}$ & $\begin{array}{c}\text { Claims on } \\
\text { central } \\
\text { governme } \\
\text { nt, etc. } \\
(\% \text { GDP) }\end{array}$ & $\begin{array}{c}\text { Internally } \\
\text { displaced } \\
\text { persons, new } \\
\text { displacement } \\
\text { associated } \\
\text { with conflict } \\
\text { and violence } \\
\text { (number of } \\
\text { cases) } \\
\end{array}$ & $\begin{array}{c}\text { Corrupti } \\
\text { on } \\
\text { Percepti } \\
\text { ons } \\
\text { Index }\end{array}$ & \begin{tabular}{|c|} 
Global \\
Terroris \\
m Index
\end{tabular} & $\begin{array}{l}\text { Happy } \\
\text { Planet } \\
\text { Index }\end{array}$ \\
\hline 1 & 0,446689 & 0,319165 & 0,604537 & ,776998 & 105238,0 & 3,000000 & 19,00000 & 9600,000 & 28,00000 & 28,00000 & 4,65000 \\
\hline 2 & 0,917014 & 0,961509 & 0,889420 & 901665 & 105237,8 & 3,000000 & 18,98612 & 9600,000 & 28,00000 & 5,50000 & 4,65000 \\
\hline 3 & 0,918919 & 0,960774 & 0,903671 & 909302 & 136809,2 & 3,000000 & 17,08751 & 8640,000 & 22,00000 & 4,50000 & 4,71000 \\
\hline 4 & 0,933354 & 0,963849 & 0,910519 & 958199 & 177851,9 & 3,000000 & 15,37876 & 8208,000 & 17,00000 & 3,50000 & 5,95000 \\
\hline 5 & 0,930361 & 0,965438 & 0,942622 & 918919 & 222314,9 & 3,000000 & 13,07194 & 7961,760 & 13,00000 & 2,50000 & 5,11000 \\
\hline
\end{tabular}

Figure 12 - Alternative predictive values of the input and output predictors of assessing the risk of using financial intermediaries for money laundering

Conclusions of this study and prospects for further research in this area. Thus, it should be noted that risk assessment of the use of financial intermediaries for money laundering based on neural networks is a very relevant, powerful and flexible tool for ensuring an effective government control system, given the need to process large datasets. This method allows automatically identifying the complex dependencies of economic processes, predicting possible results and using them when making effective decisions in the field of public administration. The introduction of this approach will allow effectively predicting and combating crimes related to money laundering and terrorism financing, will contribute to the positive economic, financial, social, political, cultural development of the country, as well as increase the country's rating in the world.

The publication contains the results of studies conducted under the grant from the President of Ukraine for the competitive project № 0119 U103189 "Development of the prototype of the automated module for financial monitoring of the economic agents activities to counteract the criminal incomes legalization". The publication was prepared as part of the Research Project "Cybersecurity in the Fight Against Banking Fraud: Protecting Consumers of Financial Services and Increasing the Financial and Economic Security of Ukraine" (state registration No. 0118U003574); Research Project "Improving the National System for Counteracting Money Laundering in the Context of Increasing Financial and Economic Security of the State" (state registration No. 0117U002251).

References.

1. David Rumelhart, James L. McClelland, and the PDP Research Group (eds., 1986): Parallel Distributed Processing: explorations in the microstructure of cognition. MIT Press, Cambridge.

2. $\quad$ Pham D.T., Packianather M.S., Afify A.A. (2007) Artificial Neural Networks. In: Andina D., Pham D.T. (eds) Computational Intelligence. Springer, Boston, MA DOIhttps://doi.org/10.1007/0-387-37452-3_3

3. World Bank Open Data. Available online: https://data.worldbank.org (accessed on 30 December 2018).

4. Organisation for Economic Co-operation and Development. Available online: https://data.oecd.org/?_ga=2.69359696.157983792.1546455347-1152323357.1544691649 (accessed on 30 December 2018).

5. Transparency

International.

Available

online:

https://www.transparency.org/news/feature/corruption_perceptions_index_2017?gclid=EAIaIQobChMIusejy-

PP3wIVVIuyCh0NdwBEEAAYASAAEgIyc_D_BwE (accessed on 30 December 2018).
6.
Institute
for economics
$\& \quad$ peace.
Available
online:

http://visionofhumanity.org/app/uploads/2017/11/Global-Terrorism-Index-2017.pdf (accessed on 30 December 2018).

7. Happy Planet Index. Available online: http://happyplanetindex.org (accessed on 30 December 2018).

8. Michael J. D. Powell; Michael J. D. Powell. Restart procedures for the conjugate gradient method (англ.) // Mathematical Programming (англ.)русск. : journal. - Springer, 1977. — Vol. 12. — Р. $241-$ 254. - DOI:10.1007/bf01593790. 
9. Broomhead, David H.; Lowe, David. Multivariable Functional Interpolation and Adaptive Networks (англ.) // Complex Systems : journal. — 1988. — Vol. 2. - P. 321-355.

10. Statistica Neural Networks, Addendum for Version 4.0, StatSoft, Inc., 1999.

11. Rosenblatt F.: The Perceptron: A Probabilistic Model for information storage and organization in the Brain // Psychological Review, 1958, V.65, pp. 386-408.

12. Rumelhart D.E, Hinton G.E., Williams R.J: Learning representation by back-propagating errors // Nature, 1986, vol.323, pp.533-536.

13. Specht D.F. Probabilistic Neural Networks // Neural Networks,1990, V.3, pp. 109-118.

14. Kohonen T. Self-organizing Maps // Proc. IEEE, 78, no.9, pp. 1464-1480.

15. Broyden-Fletcher-Goldfarb-Shanno algorithm. Available online: https://en.wikipedia.org/wiki/Broyden-Fletcher-Goldfarb-Shanno algorithm (accessed on 14 October 2019).

17. Berezhnyi O.M. (2010) Otsinka ta upravlinnia ryzykom vykorystannia posluh dlia lehalizatsii kryminalnykh dokhodiv abo finansuvannia teroryzmu $v$ komertsiinomu banku : monohrafiia [Risk Assessment and Management of the Use of Services for Legalization of Criminal Income or Financing of Terrorism in a Commercial Ban]. Sumy : DVNZ UABS NBU. (in Ukrainian)

18. Bilous V.T. (2001) Orhanizatsiino-pravove zabezpechennia borotby $z$ vidmyvanniam dokhodiv nezakonnoho pokhodzhennia: monohrafiia [Organizational and legal support of combating money laundering of illegal origin: monograph].Irpin: Akademiia DPS.(in Ukrainian)

19. Hurzhii S. H., O.L. Kopylenko, Ya.V. Yanushevych ta in. (2005) Borotba z vidmyvanniam koshtiv: pravovyi, orhanizatsiinyi ta praktychnyi aspekty [Anti-money laundering: legal, organizational and practical aspects]. K.: Parlament. vyd-vo.(in Ukrainian)

20. Marchuk R.P., O.I.Popov, V.A.Onisiev. (2008) Borotba z lehalizatsiieiu (vidmyvanniam) dokhodiv, oderzhanykh zlochynnym shliakhom i finansuvanniam teroryzmu: navchalnyi posibnyk T. 1.: Mizhnarodni normatyvnopravovi akty ta standarty [Combating the legalization (laundering) of proceeds of crime and terrorist financing: a textbook. Volume 1: International Regulations and Standards].K.: Mizhnarodna ahentsiia "Bizon". (in Ukrainian)

21. Vnukova N.M., Kolodiziev O.M., Chmutova I.M. (2017) Analiz mizhnarodnoho dosvidu zastosuvannia ryzyk-oriientovanoho pidkhodu u sferi protydii vidmyvanniu koshtiv, finansuvanniu teroryzmu ta rozpovsiudzhennia zbroi masovoho znyshchennia [ An analysis of the international experience of applying a risk-oriented approach in the field of combating money laundering, terrorist financing and the proliferation of weapons of mass destruction]. Hlobalni ta natsionalni problemy ekonomiky, vol.17, pp. 610-617.

22. Dmytrov S.O., Merenkova O.V., Medvid T.A., Vashchenko O.M. (2010) Otsinka ta upravlinnia ryzykom vykorystannia posluh dlia lehalizatsii kryminalnykh dokhodiv abo finansuvannia teroryzmu v komertsiinomu bank: monohrafiia [Risk Assessment and Management of Use of Services to Criminal Income or Terrorism Financing at a Commercial Bank: Monograph]. Sumy: DVNZ «UABS NBU». (in Ukrainian)

23. Zakharov V.P. (2014) Lehalizatsiia (vidmyvannia) dokhodiv, oderzhanykh zlochynnym shliakhom: teoretyko-pravovyi aspekt [ Legalization (laundering) of proceeds of crime: theoretical and legal aspect]. Visnyk Natsionalnoho universytetu "Lvivska politekhnika". Yurydychni nauky, no.801,pp. 180-186.

24. Yvanov D.V. Prohnozyrovanye fynansovыkh ronkov s yspolzovanyem yskusstvennыkh neironnыkh setei [Forecasting financial markets using artificial neural networks] (electronic journal) Available at: (forexmmcis.ru./D.Ivanov). (accessed on 22 September 2019)

25. Kadnichanska V.M., Romas T.O. (2013) Otsinka ryzyku lehalizatsii dokhodiv, oderzhanykh zlochynnym shliakhom, i finansuvannia teroryzmu [Risk assessment of legalization of proceeds from crime and terrorist financing]. Visnyk Universytetu bankivskoi spravy natsionalnoho banku Ukrainy, vol.1, no.16, pp.251-254/

26. Matviichuk A. (2010) Modeliuvannia finansovoi stiikosti pidpryiemstv iz zastosuvanniam teorii nechitkoi lohiky, neironnykh merezh i dyskryminatnoho analizu [Simulation of financial stability of enterprises using the theories of fuzzy logic, neural networks and discriminant analysis]. Visn. NAN Ukrainy, no. 9, pp. 24-46.

27. Mozolevska M. O. (2017) Vykorystannia neironnykh merezh dlia prohnozuvannia u finansovii sferi [Use of neural networks for forecasting in financial sphere]. Aktualni problemy ekonomiky ta upravlinnia : zbirnyk naukovykh prats molodykh vchenykh [Actual problems of economics and management: a collection of scientific works of young scientists]. (electronic journal) vol.11. Available at: (http://ela.kpi.ua/handle/123456789/22609). (accessed on 22 September 2019).

28. Moskalenko N.V., Klymchuk N.Ia. (2017) Upravlinnia ryzykamy lehalizatsii dokhodiv, oderzhanykh zlochynnym shliakhom [Management of the risks of legalization of proceeds from crime]. Zbirnyk naukovykh prats Universytetu derzhavnoi fiskalnoi sluzhby Ukrainy, no. 1, pp. 183-194.

29. Rysin V. (2008) Kryterii otsinky ryzykiv, poviazanykh z vidmyvanniam hroshei, u protsesi formuvannia resursnoi polityky banku [Criteria for assessing money laundering risks in the process of forming a bank's resource policy]. Visnyk Lviv. un-tu, vol. 39, pp.473-475.

30. Setlak H. (2004) YSPOLZOVANYE YSKUSSTVENNHKh NEIRONNHKh SETEI DLIa REShENYIa ZADACh KLASSYFYKATSYY V MENEDZhMENTE [USE OF ARTIFICIAL NEURAL NETWORKS TO SOLVE CLASSIFICATION PROBLEMS IN MANAGEMENT]. Radioelektronika. Informatyka. Upravlinnia no.1, pp.127135.

31. Smahlo O.V. (2015) Udoskonalennia systemy otsiniuvannia ryzykiv lehalizatsii zlochynnykh dokhodiv pry zdiisnenni zovnishnoekonomichnoi diialnosti [Improvement of the system of estimation of risks of legalization of criminal incomes during realization of foreign economic activity]. Teoriia ta metodolohiia bukhhalterskoho obliku, kontroliu, analizu : Mizhnar. zb. nauk. pr.. / Seriia : Bukhhalterskyi oblik, kontrol i analiz, vol.2, no.32. 
32. Khudokormova M.I. (2012) Metodyka otsiniuvannia ryzyku kliienta pry vykorystanni nym posluh banku dlia lehalizatsii kryminalnykh dokhodiv [Methods of assessing the risk of the client when using his services of the bank for the legalization of criminal incomes]. Aktualni problemy ekonomiky, no. 6, pp. 283-289.

33. Chmutova I.M. (2018) Finansova stiikist banku yak indykator ryzyku vidmyvannia koshtiv ta finansuvannia teroryzmu [Bank Financial Sustainability as an Indicator of Money Laundering and Terrorist Financing Risk]. Ekonomika i suspilstvo. MUKAChIVSKYI DERZhAVNYI UNIVERSYTET, vol.14, pp.867-875.

\section{Лiтература.}

1. David Rumelhart, James L. McClelland, and the PDP Research Group (eds., 1986): Parallel Distributed Processing: explorations in the microstructure of cognition. MIT Press, Cambridge.

2. $\quad$ Pham D.T., Packianather M.S., Afify A.A. (2007) Artificial Neural Networks. In: Andina D., Pham D.T. (eds) Computational Intelligence. Springer, Boston, MA DOIhttps://doi.org/10.1007/0-387-37452-3_3

3. World Bank Open Data. Available online: https://data.worldbank.org (accessed on 30 December 2018).

4. Organisation for Economic Co-operation and Development. Available online: https://data.oecd.org/? ga $=2.69359696 .157983792 .1546455347-1152323357.1544691649$ (accessed on 30 December 2018).
5. Transparency
International.
Available
online:

https://www.transparency.org/news/feature/corruption_perceptions_index_2017?gclid=EAIaIQobChMIusejy-

PP3wIVVIuyCh0NdwBEEAAYASAAEgIyc D B BwE (accessed on 30 December 2018).

6. Institute for economics \& peace. Available online:

http://visionofhumanity.org/app/uploads/2017/11/Global-Terrorism-Index-2017.pdf (accessed on 30 December 2018).

7. Happy Planet Index. Available online: http://happyplanetindex.org (accessed on 30 December 2018).

8. Michael J. D. Powell; Michael J. D. Powell. Restart procedures for the conjugate gradient method (англ.) // Mathematical Programming (англ.)русск. : journal. — Springer, 1977. — Vol. 12. — P. 241254. - DOI:10.1007/bf01593790.

9. Broomhead, David H.; Lowe, David. Multivariable Functional Interpolation and Adaptive Networks (англ.) // Complex Systems : journal. — 1988. — Vol. 2. — P. 321-355.

10. Statistica Neural Networks, Addendum for Version 4.0, StatSoft, Inc., 1999.

11. Rosenblatt F.: The Perceptron: A Probabilistic Model for information storage and organization in the Brain // Psychological Review, 1958, V.65, pp. 386-408.

12. Rumelhart D.E, Hinton G.E., Williams R.J: Learning representation by back-propagating errors // Nature,1986, vol.323, pp.533-536.

13. Specht D.F. Probabilistic Neural Networks // Neural Networks,1990, V.3, pp. 109-118.

14. Kohonen T. Self-organizing Maps // Proc. IEEE, 78, no.9, pp. 1464-1480.

15. Алгоритм Бройдена — Флетчера - Гольдфарба - Шанно. Режим доступу: https://uk.wikipedia.org/wiki/Алгоритм_Бройдена___Флетчера___Гольдфарба___Шанно (станом на 14 жовтня 2019)

16. Бережний О.М. Оцінка та управління ризиком використання послуг для легалізації кримінальних доходів або фінансування тероризму в комерційному банку : монографія / О.М.Бережний. - Суми : ДВНЗ УАБС НБУ, 2010. - 114c.

17. Білоус В.Т. Організаційно-правове забезпечення боротьби з відмиванням доходів незаконного походження: монографія/В.Т. Білоус, В.М. Попович, М.В. Попович. - Ірпінь: Академія ДПС, 2001. - 137 с.

18. Боротьба з відмиванням коштів: правовий, організаційний та практичний аспекти/С. Г. Гуржій, О.Л. Копиленко, Я.В. Янушевич та ін. - К.: Парламент. вид-во, 2005. - 216 с.

19. Боротьба 3 легалізацією (відмиванням) доходів, одержаних злочинним шляхом i фінансуванням тероризму: навчальний посібник/Р.П. Марчук, О.І.Попов, В.А.Онісьєв. - Т. 1.: Міжнародні нормативно-правові акти та стандарти. - К.: Міжнародна агенція “Бізон”, 2008. - 384 с.

20. Внукова Н.М., Колодізєв О.М., Чмутова І.М. Аналіз міжнародного досвіду застосування ризикорієнтованого підходу у сфері протидії відмиванню коштів, фінансуванню тероризму та розповсюдження зброї масового знищення // Глобальні та національні проблеми економіки. 2017. Вип. 17. С. 610-617.

21. Дмитров С.О., Меренкова О.В., Медвідь Т.А., Ващенко О.М. Оцінка та управління ризиком використання послуг для легалізації кримінальних доходів або фінансування тероризму в комерційному банк : монографія / за заг. ред. О.М. Бережного. Суми: ДВНЗ «УАБС НБУ», 2010. 114 с.

22. Захаров В.П. Легалізація (відмивання) доходів, одержаних злочинним шляхом: теоретикоправовий аспект/В.П. Захаров // Вісник Національного університету “Львівська політехніка”. Юридичні науки. - 2014. - №801. - С. 180-186.

23. Иванов Д.В. Прогнозирование финансовых рынков с использованием искусственных нейронных сетей [Електронний ресурс] / Д. В. Иванов - Режим доступу до ресурсу:forex-mmcis.ru./D.Ivanov. (accessed on 22 September 2019).

24. Каднічанська В.М., Ромась Т.О. Оцінка ризику легалізації доходів, одержаних злочинним шляхом, і фінансування тероризму // Вісник Університету банківської справи національного банку України. 2013. №1(16). C.251-254. 
25. Матвійчук А. Моделювання фінансової стійкості підприємств із застосуванням теорій нечіткої логіки, нейронних мереж і дискримінатного аналізу // Вісн. НАН України. — 2010. — № 9. - С. 24-46.

26. Мозолевська М. О. Використання нейронних мереж для прогнозування у фінансовій сфері [Електронний ресурс] / Мозолевська М. О., Ставицький О. В. // Актуальні проблеми економіки та управління : збірник наукових праць молодих вчених. - Електронні текстові дані. - 2017. - Вип. 11. Режим доступу до pecypcy: http://ela.kpi.ua/handle/123456789/22609. (accessed on 22 September 2019).

27. Москаленко Н.В., Климчук Н.Я. Управління ризиками легалізації доходів, одержаних злочинним шляхом // Збірник наукових праць Університету державної фіскальної служби України. 2017. № 1. C. $183-194$.

28. Рисін В. Критерії оцінки ризиків, пов'язаних з відмиванням грошей, у процесі формування ресурсної політики банку // Вісник Львів. ун-ту. 2008. Вип. 39. С.473-475.

29. Сетлак Г. Использование искусственных нейронных сетей для решения задач классификации в менеджменте // Радіоелектроніка. Інформатика. Управління. №1, 2004. С.127-135.

30. Смагло О.В. Удосконалення системи оцінювання ризиків легалізації злочинних доходів при здійсненні зовнішньоекономічної діяльності // Теорія та методологія бухгалтерського обліку, контролю, аналізу : Міжнар. зб. наук. пр.. / Серія : Бухгалтерський облік, контроль і аналіз. - Вип.2(32). - Житомир: ЖДТУ, 2015.

31. Худокормова М.I. Методика оцінювання ризику клієнта при використанні ним послуг банку для легалізації кримінальних доходів // Актуальні проблеми економіки. 2012. № 6. С. 283-289.

32. Чмутова I.М. Фінансова стійкість банку як індикатор ризику відмивання коштів та фінансування тероризму // Економіка і суспільство. МУКАЧІВСЬКИЙ ДЕРЖАВНИЙ УНІВЕРСИТЕТ. 2018. Випуск №14. C.867-875.

33. Lyeonov, S., Kuzmenko, O., Yarovenko, H. \& Dotsenko, T. (2019). The Innovative Approach to Increasing Cybersecurity of Transactions Through Counteraction to Money Laundering. Marketing and Management of Innovations, 3, 308-326. http://doi.org/10.21272/mmi.2019.3-24 